\title{
Motivasi Peserta Didik dalam Mengikuti Pembelajaran Pjok di Masa Pandemi Covid-19
}

\author{
Joni Arta Santosa ${ }^{1 *}$ \\ ${ }^{1}$ Jurusan Pendidikan Olahraga, Universitas Pendidikan Ganesha, Singaraja, Indonesia
}

\section{ART ICLE IN F O \\ Article history: \\ Received January 17, 2021 \\ Revised January 19, 2021 \\ Accepted April 07, 2021 \\ Available online July 25, 2021}

Kata Kunci:

Sarana, Prasarana, PJOK

Keywords:

Facilities, Infrastructure, PJOK

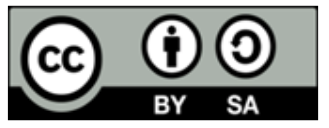

This is an open access article under the CC BY-SA license.

Copyright $(\subseteq 2021$ by Author. Published by Universitas Pendidikan Ganesha.

\begin{abstract}
A B S T R A K
Pandemi covid-19 yang terjadi saat ini memiliki dampak yang cukup signifikan terhadap pembelajaran pendidikan jasmani, olahraga, dan kesehatan. Hal tersebut dapat mempengaruhi motivasi peserta didik dalam berolahraga di masa pandemic covid-19. Dengan begitu penelitian ini bertujuan untuk mengetahui motivasi peserta dalam mengikuti pembelajaran PJOK dimasa pandemi covid-19 tahun ajaran 2020/2021. Penelitian ini adalah penelitian deskriptif kuantitatif dengan jenis penelitian survei. Populasi penelitian ini adalah peserta didik yang berjumlah 165 orang. Sampel penelitian ini menggunakan non rondom sampling yaitu quota sampling dengan besaran $25 \%$ dari total populasi sehingga jumlah sampel dalam penelitian ini adalah 41 orang. Data dianalisis menggunakan statistik deskriptif kuantitatif dengan kategori interval. Hasil penelitian ini adalah dari 41 orang peserta didik sebanyak 14 orang berkategori sangat tinggi, 26 orang berkategori tinggi dan 1 orang berkategori sedang. Hasil penelitian menunjukkan motivasi peserta didik dalam mengikuti pembelajaran PJOK di masa pandemi covid-19 mendapat skor rata-rata 63 dalam skala kategori dikatakan tinggi. Kesimpulan dari penjabaran diatas ialah motivasi peserta didik dalam mengikuti pembelajaran PJOK di masa pandemi covid-19 tahun ajaran 2020/2021 berkategoi tinggi.
\end{abstract}

\section{A B S T R A K}

The current COVID-19 pandemic has had a significant impact on learning physical education, sports, and health. This can affect the motivation of students in exercising during the COVID-19 pandemic. Thus, this study aims to determine the motivation of participants in participating in PJOK learning during the COVID-19 pandemic for the 2020/2021 academic year. This research is quantitative descriptive research with the type of survey research. The population of this study were students, amounting to 165 people. The sample of this study used non-random sampling, namely quota sampling with a size of $25 \%$ of the total population so that the number of samples in this study was 41 people. Data were analyzed using quantitative descriptive statistics with interval categories. The results of this study were from 41 students, 14 students were in very high category, 26 students were in high category and 1 person was in moderate category. The results showed that the motivation of students in participating in PJOK learning during the COVID-19 pandemic got an average score of 63 on a category scale that was said to be high. The conclusion from the description above is that the motivation of students to take part in PJOK learning during the COVID-19 pandemic for the 2020/2021 school year is categorized as high.

\section{PENDAHULUAN}

Pandemi Covid 19 yang terjadi di seluruh dunia memaksa masyarakat untuk mengubah makna pola hidup dan kehidupan sehari-hari yang berdampak pada semua aspek kehidupan. Dampak covid-19 ini memaksa semua kebijakan sosial distancing atau physical distancing (menjaga jarak fisik) dilakukan untuk meminimalisir dan mencegah penyebaran virus (Ardan, Rahman, \& Geroda, 2020; Buana, 2020; Suryaningtyas, 2020) Akibatnya masyarakat harus melihat perubahan-perubahan di bidang ekonomi, sosial, politik hingga pendidikan (Ismawati \& Prasetyo, 2021; Sadikin, A., \& Hamidah, 2020). 
Pendidikan menjadi hal yang sangat penting untuk bertumbuh dan berkembang. Pendidikan merupakan salah satu hal penting yang direncanakan untuk pembangunan Negara (Hasmori, Sarju, \& Norihan, 2011; Pambudi, Winarno, \& Dwiyogo, 2019). Pendidikan adalah wadah bagi seseorang untuk mengetahui serta mengembangkan ilmu dan bakat yang ada pada dirinya untuk berkembang kearah yang lebih baik. Namun saat pandemic covid 19 terjadi, pemerintah membuat peraturan dalam dunia pendidikan dengan melarang pelaksanaan kegiatan pembelajaran secara tatap muka, dan semua harus dilaksanakan secara daring (online) guna meminimalisir penyebaran viru covid 19. Pembelajaran daring atau dikenal juga dengan pembelajaran jarak jauh atau remote yang telah menjadi entitas ubiquitous (Allen \& Seaman, 2016). Ubiquitous learning (U-Learning) yaitu konten digital, lingkungan fisik, alat-alat seluler, komponen yang mempengaruhi, komunikasi tanpa kabel yang memberikan pengalaman belajarmengajar pada pengguna yang dilakukan kapan saja dan dimana saja (Cárdenas-Robledo, L. A., \& PeñaAyala, 2018). Pembelajaran online merupakan hal baru dan menjadi tantangan tersendiri bagi sebagian besar murid, guru maupun orang tua . Pembelajaran secara daring dilakukan oleh seluruh jenjang pendidikan mulai dari paud hingga perkuliahan, begitupula terhadap materi pembelajarannya, guru dosen, menyampaikan materi secara online tidak terkecuali pembelajaran PJOK.

PJOK merupakan sebuah pembelajaran untuk bergerak melalui gerak yang diintegrasikan dengan ilmu pengetahuan serta cabang olahraga sehingga dapat diterima oleh peserta didik (Faridah, 2016; Ramadhana \& Tuasikal, 2018). Mata pelajaran penjas memiliki ciri khas pada aktivitas gerak dan dilaksanakan di luar ruang kelas (Ginanjar, Suherman, Juliantine, \& Hidayat, 2020; Stephani, 2017). Pendidikan jasmani sangat penting bagi siswa karena mampu menumbuhkan pola hidup sehat, serta mengembangkan aspek kebugaran jasmani, keterampilan gerak, keterampilan berfikir kritis, keterampilan sosial, penalaran, stabilitas emosional, tindakan moral, aspek pola hidup sehat dan pengenalan lingkungan bersih melalui aktivitas jasmani (Lesmana, 2018; Mashuri, 2017) Mata pelajaran PJOK adalah kegiatan pembelajaran disekolah yang sangat berpengaruh karena memberikan pengaruh yang postif pada perkembangan siswa (Koc, 2017). Pembelajaran PJOK yang diajarkan disekolah memiliki peranan yang sangat penting, yaitu memberikan kesempatan kepada peserta didik untuk terlibat langsung dalam berbagai pengalaman belajar melalui aktivitas jasmani dan olahraga yang terpilih dan dilakukan secara sistematis (Hartanti, Nurhasan, \& Tuasikal, 2020). Dalam proses pembelajaran khususnya PJOK, pendidik (guru) memegang peranan yang sangat penting. Pendidik merupakan seseorang atau orang yang memiliki tanggung jawab dalam memberikan pendidikan dan mentransfer ilmu pengetahuan (Ramli, 2015). Guru profesional termasuk juga guru PJOK diharapkan mampu merancang pembelajaran yang interaktif, inspiratif, menyenangkan, menantang, memotivasi peserta didik untuk berpastisipasi aktif dalam proses pembelajaran(Yulianto, Roesdiyanto, \& Sugiharto, 2017). Peran guru PJOK ialah kualitas SDM meningkat dengan berbagai aktivitas jasmani (Arifin, 2017). Namun terjadinya pandemic covid 19, yang mengharuskan proses pembelajaran secara daring, sangat berdampak terhadap proses pembelajaran.

Berdasarkan observasi yang telah dilakukan di SMP Negeri 4 Sukasada, pembelajaran PJOK atau pendidikan jasmani, olahraga, dan kesehatan tetap dilakukan. Pemberian pembelajaran PJOK dilakukan dengan cara daring. Dalam observasi yang telah dilakukan, guru di SMP Negeri 4 Sukasada telah melaksakan proses pembelajarn secara daring dengan memberikan pembelajaran lewat video atau penjelasan yang diberikan melalui grup. Namun pembelajaran secara daring menimbulkan beberapa hal yang dapat menurunkan motivasi siswa dalam pembelajaran PJOK di masa pandemi. Sehingga banyak siswa yang malam untuk berolahraga. Faktor penyebab rendahnya motivasi siswa yaitu kurang pahamnya siswa terhadap materi yang diberikan serta fasilitas yang kurang mendukung untuk melakukan olahraga dirumah. Selain itu, bimbingan atau arahan dari guru yang dirasa belum maksimal karena terhalang oleh pembelajaran daring. Disisi lain, penerapan teknologi dalam pembelajaran di sekolah belum merata dan optimal. Tidak sedikit guru-guru selama ini belum memahami bahkan dapat memanfaatkan teknologi dalam pembelajarannya (Sadikin, Lestari, \& Aini, 2020). Hal ini berdampak pada guru kesulitan menyampaikan materi kepada siswa, sehingga menyebabkan siswa malas untuk belajar karena kesulitan memperoleh materi. Pembelajaran pendidikan jasmani yang seperti itu membuat siswa mengalami kejenuhan karena merasa gagal dan tidak mampu melakukan suatu permainan olahraga (Bildhonn Y, 2017). Oleh karena itu dalam prose pembelajaran, peserta didik sangat membutuhkan dorongan untuk berkembang dan mempelajari hal baru. Dalam hal ini motivasi peserta didik dalam pendidikan jasmani atau berolahraga sangat diperlukan.

Motivasi merupakan komponen penting yang dapat mendorong siswa untuk belajar (Amna Emda, 2017; Harianto \& Hartati, 2016). Motivasi adalah dorongan yang muncul dalam diri seseorang untuk melakukan suatu perubahan baik dalam perbuatan maupun perilaku (Fauziah, 2017; Oktiani, 2017; Wirawan, 2017) Motivasi belajar seorang siswa tidak akan tumbuh begitu saja tanpa ada kemauan yang kuat dari dalam diri siswa itu sendiri atau dapat tumbuh apabila ada seseorang yang merangsangnya 
dengan berbagai cara. Motivasi dapat dibagi menjadi 2 jenis motivasi yaitu motivasi yang berasal dari luar atau motivasi ekstrinsik dan motivasi yang berasal dari dalam diri atau motivasi instrinsik (Islamiyah \& Priambodo, 2019; Sardiman, 2011). Dapat dikatakan bahwa peran motivasi pada pendidikan olahraga sangatlah penting. Namun, dalam kondisi saat ini ditengah pandemi covid-19 peserta didik tidak dapat mengikuti pembelajaran sebagai mana mestinya khususnya terkait pembelajaran olahraga sehingga hal tersebut di khawatirkan mempengaruhi motivasi siswa dalam berolahraga.

Beberapa penelitian telah dilakukan terkait dengan motivasi siswa dalam pembelajaran jasmani, olahraga, dan kesehatan yaitu 1) penelitian oleh Sjukur (2013) yang mengungkapkan bahwa siswa memiliki motivasi yang tinggi dalam mengikuti pembelajaran melalui metode blended learning. 2) penelitian oleh (Herlina dan Suherman, 2020) terkait dengan potensi pembelajaran PJOK di tengah pandemi covid-19 di sekolah dasar yang mengungkap bahwa peserta didik dapat mengikuti pembelajaran daring namun diperlukannya metode blanded learning atau menggabungkan dua metode pembelajaran. 3) penelitian oleh (Ramadhani, Mahardika, \& Indahwati, 2021) yang menunjukkan motivasi belajar siswa sangat tinggi dan tingkat pemahaman siswa yang dilihat dari hasil belajar siswa menunjukkan nilai lulus KKM. Penelitian mengenai motivasi belajar siswa dalam mengikuti pembelajaran PJOK telah diteliti berbagai tempat dengan hasil yang bervariasi. Yang membedakan antara penelitian ini dengan penelitian sebelumnya yakni pada penelitian ini diteliti mengenai motivasi peserta didik dalam mengikuti pembelajaran PJOK selama masa pandemic covid 19 pada jenjang Sekolah Menengah Pertama., Sehingga tujuan penelitian ini yaitu untuk mengetahui motivasi peserta didik kelas IX di SMP Negeri 4 Singaraja dalam megikuti pembelajaran PJOK di masa pandemi covid-19.

\section{METODE}

Penelitian ini merupakan penelitian deskriptif kuantitatif dengan jenis penelitian survei. Dalam penelitian ini, peneliti tidak memberikan perlakuan, tetapi langsung mengambil data dari sumber data. Penelitian ini dirancang untuk mendeskripsikan dan menjelaskan motivasi peserta didik dalam mengikuti pembelajaran PJOK di masa pandemi covid-19. Dalam penelitian ini terdapat tiga proses yang telah dilewati yaitu perencanaan, pelaksanaan, dan pelaporan hasil penelitian. Dalam proses perencanaan dilakukan analisis kebutuhan sehingga dapat disesuaikan dengan instrumen yang digunakan. Selanjutnya, pada pelaksanaan dilakukan pengambilan dan analisis data serta pembahasan. Teknik pengumpulan data dalam penelitian ini menggunakan kuisioner, dimana kuisioner yang disebarkan terdapat 20 pernyataan yang terdiri dari 16 pernyataan positif dan4 pernyataan negatif. Jawaban peserta didik diklasifikasikan yaitu sangat setuju (SS), Setuju (S), Tidak Setuju (TS) dan Sangat Tidak Setuju (STS).Kuisioner yang disebar kepada responden telah melalui uji validitas dengan bantuan ahli/pakar pada bidangnya. Serta telah melakukan uji reliabilitas untuk memperkuat kelayakan instrument sebagai alat ukur penelitian terkait dengan motivasi peserta didik kelas IX dalam mengikuti pembelajaran PJOK di masa pandemi covid-19. Analisis data dilakukan dengan menganalisis secara deskriptif hasil penelitian dan dilanjutkan dengan pelaporan hasil analisis terkait dengan motivasi peserta didik kelas IX dalam mengikuti pembelajaran PJOK di masa pandemi covid-19. Populasi dalam penelitian ini adalahseluruh peserta didik kelas IX SMP Negeri 4 Sukasada tahun pelajaran 2020/2021 yang terdistribusi ke dalam 5 kelas sehingga keseluruhan jumlah subjek penelitian adalah 165 orang. Adapun dalam penelitian ini pengambilan sampel menggunakan non random sampling yang dilakukan dengan cara quota sampling yang artinya pengambilan sampel dengan menetapkan subjek yang akan diteliti. Oleh karena itu, sample yang terlibat dalam penelitian ini merupakan 25\% dari total keseluruhan populasi yaitu sebanyak 41 peserta didik kelas IX SMP Negeri 4 Sukasada.

\section{HASIL DAN PEMBAHASAN}

Hasil yang ditunjukan pada penelitian saat ini adalah motivasi peserta didik kelasIX di SMP Negeri 4 Sukasada yang dinilai dari tingkat motivasi mereka dalam berolahraga di masa pandemi covid19. Alat ukur yang digunakan dalam mengukur motivasi peserta didik yaitu kuisioner yang disebar kepada responden yaitu siswa SMP Negeri 4 Sukasada. Kuisioner yang digunakan telah melalui uji validitas yang diuji oleh dua ahli dalam bidangnya. Penelitian yang telah dilakukan pada Selasa, 6 Oktober 2020 ini dilakukan melalui google form untuk memudahkan pengambilan data berbasis daring. Berdasarkan penelitian yang telah dilakukan maka didapatkan hasil sebagai berikut. Tabel 1 menunjukan bahwa dari 41 peserta didik yang memberikan respon terhadap kuisioner terkait dengan motivasi peserta didik dalam mengikuti pembelajaran PJOK di masa pandemi covid-19, sebanyak 14 orang peserta didik memiliki motivasi yang sangat tinggi, sebanyak 26 peserta didik yang memiliki motivasi yang tinggi, 
dan hanya 1 peserta didik dari keseluruhan responden yang memberikan respone terkait motivasi peserta didik yang memiliki motivasi yang sedang. Setelah melakukan analisis terhadap hasil kuisioner yang telah disebar, maka tahap selanjutnya yaitu menentukan tingkat motivasi peserta didik dalam mengikuti pembelajaran PJOK di masa pandemi covid-19. Berdasarkan hasil yang telah ditunjukan pada penelitian saat ini, dapat dismpulkan bahwa motivasi peserta didik kelas IX SMP Negeri 4 Sukasad dalam mengikuti pembelajaran PJOK dimasa pandemi covid-19 dapat dikategorikan dalam motivasi yang tinggi. Hal tersebut sesuai dengan hasil yang menunjukan bahwa banyaknya peserta didik yang memiliki motivasi sangat tinggi dan tinggi. Hal ini mengindikasikan bahwa peserta didik memberikan respon yang positif terhadap kegiatan olahraga yang tetap dilakukan dimasa pandemi covid-19. Hal ini juga didukung oleh hasil perhitungan rata-rata skor motivasi peserta didik yang memperoleh hasil sebesar 63. Skor tersebut mengindikasikan bahwa siswa kelas IX SMP Negeri 4 Sukasada memiliki keinginan dari dalam diri sendiri serta dipengaruhi oleh factor intrinsik dan ekstrinsik.

Tabel 1. Hasil Analisis Motivasi Peserta Didik Kelas IX di SMP Negeri 4 Sukasada

\begin{tabular}{ccc}
\hline No. & Kategori & Jumlah \\
\hline 1. & Sangat Tinggi & 14 \\
2. & Tinggi & 26 \\
3. & Sedang & 1 \\
4. & Rendah & 0 \\
5. & Sangat Rendah & 0 \\
\hline
\end{tabular}

Hasil yang telah dipaparkan mengungkapkan bahwa pandemi covid-19 tidak menjadi halangan yang begitu berarti karena siswa memiliki motivasi yang tinggi untuk tetap berolahraga di masa pandemi. Keinginan yang tinggi dipengaruhi oleh adanya dorongan dan kesadaran dalam diri sendiri serta mengetahui pentingnya berolahraga. Pentingnya olahraga di masa saat ini berguna untuk menjaga daya tahan tubuh serta kebugaran tubuh. Motivasi siswa yang tinggi dalam pembelajarn PJOK dipengaruhi oleh faktor ekstrinsik dan intrinsik. Faktor intrinsik merupakan dorongan dari dalam diri siswa dalam mengikuti pembelajaran PJOK berbasis daring. Dorongan tersebut dapat berupa dorongan dalam diri berupa kesehatan, minat, bakat dan perhatian. Faktor ekstrinsik merupakan dorongan yang berasal dari luar diri siswa dalam mengikuti pembelajaran PJOK berbasis daring. Motivasi ekstrinsik merupakan faktor penting dalam pembelajaran, karena tidak semua proses dan/atau materi pelajaran merupakan minat atau bakat siswa dan belum munculnya kesadaran siswa akan pentingnya bahan pelajaran yang disampaikan oleh guru. Dalam keadaan tersebut siswa membutuhkan stimulus/dorongan untuk menciptakan motivasi belajar siswa. Dorongan dari luar dapat berupa metode mengajar yang menarik, alat pelajaran yang inovatif, kondisi lingkungan yang menyenangkan. Sehingga dapat dikatakan bahwa faktor eksternal yang sangat berpengaruh adalah guru dan keluarga. Guru berperan sebagai pendidik yang mengajarkan nilai-nilai, akhlak, moral maupun sosial dan untuk menjalankan peran tersebut seorang guru dituntut untuk memiliki pengetahuan dan wawasan yang luas yang nantinya akan diajarkan kepada siswa (Arianti, 2019). Guru merupakan kunci inti dalam proses pembelajaran, baik dalam meningkatkan kualitas pendidikan maupun dalam memberikan motivasi belajar kepada siswa (Idzhar, 2016). Dalam melaksanakan pembelajaran PJOK peran guru diharapkan mampu mendesain proses belajar mengajar yang kondusif serta menentukan metode yang tepat dalam menyampaikan materi ajarnya yang sesuai dengan karakteristik peserta didik atau karakteristik kelas yang diaja (Hartanti et al., 2020). Begitupula dengan lingkungan keluarga. Keluarga merupakan lingkungan pertama bagi anak. Di lingkungan keluarga inilah anak mendapatkan pendidikan yang pertama dan utama. Saat pandemi seperti sekarang orang tua bertugas membantu anak dalam mempersiapkan media yang akan digunakan anak, mendampingi proses belajarnya dan masih banyak lagi peran orang tua yang dapat memaksimalkan proses belajar mengajar di rumah melalui daring (Iftitah \& Anawaty, 2020). Lingkungan keluarga yang positif berdampak pada motivasi belajar, semakin bagus serta positif lingkungan keluarga maka semakin bagus juga motivasi belajarnya (Rachmah, Sunaryanto, \& Yuniastuti, 2019).

Motivasi adalah adalah dorongan internal dan eksternal pada peserta didik yang sedang belajar untuk mengadakan perubahan perilaku (Astuti, Novita, \& Ismail, 2020) (Ayatollah, 2018) Motivasi merupakan penggerak atau pendorong untuk melakukan tindakan tertentu. Tinggi rendahnya motivasi dapat menentukan tinggi rendahnya usaha atau semangat seseorang untuk beraktivitas, dan tentu saja tinggi rendahnya semangat akan menentukan hasil diperoleh (Elida, 2018; Jamal, 2017) Motivasi belajar baik intrinsik maupun ekstrinsik harus dimiliki siswa karena dapat memberikan semangat kepada siswa sehingga ia dapat mengetahui arah belajarnya untuk mencapai tujuan pembelajaran yang telah ditetapkan (A. Emda, 2018). Adanya motivasi belajar harus diupayakan ada dalam diri siswa, apalagi saat pandemic seperti sekarang, harus tercipta kerjasama antara guru dan orangtua agar siswa mampu 
meningkatkan motivasinya untuk belajar. Sehingga hasil yang ingin dicapai sebagai hasil dari pembelajaran dapat diperoleh secara maksimal.

Hasil pada penelitian ini relevan dengan beberapa hasil penelitian yang telah dilakukan yaitu 1) penelitian oleh (Herlina dan Suherman, 2020) yang menyatakan bahwa siswa dapat mengikuti pembelajaran PJOK dengan baik dan terkendali meskipun terdapat beberapa faktor yang menjadi hambatan dalam belajar. Penelitian oleh (Munandar dan Hartati, 2016) juga mengungkapkan bahwa motivasi memiliki peran yang penting dalam pembelajaran jasmani, olahraga, dan kesehatan pada siswa kelas tiga dan lima di sekolah dasar.. Motivasi yang tinggi juga dapat mempengaruhi hasil belajar siswa. Oleh karena itu motivasi menjadi hal yang sangat berperan dalam pembelajaran. Erat kaitannya dengan kondisi saat ini yang terkendala dengan fasilitas untuk menunjang kegiatan olahraga siswa.

\section{SIMPULAN DAN SARAN}

Berdasarkan pembahasan yang telah dilakukan, dapat disimpulkan bahwa motivasi siswa kelas IX SMP Negeri 4 Sukasada memiliki motivasi yang tinggi dalam berolahraga di masa pandemic covid-19. Hal tersebut dibuktikan dengan banyaknya siswa yang memiliki motivasi yang tinggi dari total seluruh responden dalam penelitian ini. Motivasi belajar peserta didik atau siswa dipengaruhi oleh factor instrinsik dan ekstrinsik. Oleh karena itu peserta didik dapat meningkatkan motivasi yang telah dimiliki guna menjaga dayatahan serta kebugaran tubuh di tengah penyebaran virus yang semakin meluas. Selain itu, guru dapat memilih cara lain untuk menyampaikan pembelajaran jasmani, olahraga, dan kesehatan agar dapat diterima dengan mudah oleh peserta didik. Kemudian, peneliti selanjutnya dapat mengembangkan serta menambah cakupan penelitian untuk mendapat hasil yang lebih maksimal.

\section{DAFTAR RUJUKAN}

Allen, I. E., \& Seaman, J. (2016). Online Report Card: Tracking Online Education in the United States . Babson Park, MA: Babson Survey Research Group and Quahog Research Group.

Ardan, M., Rahman, F. F., \& Geroda, G. B. (2020). The influence of physical distance to student anxiety on COVID-19, Indonesia. Journal of Critical Reviews, 7(17), 1126-1132. https://doi.org/10.31838/jcr.07.17.141.

Arianti, A. (2019). Peranan Guru Dalam Meningkatkan Motivasi Belajar Siswa. Didaktika: Jurnal Kependidikan, 12(2), 117-134.

Arifin, S. (2017). Peran Guru Pendidikan Jasmani Dalam Pembentukan Pe ndidikan Karakter Peserta Didik. Jurnal Multilateral, 16(1), 78 - 92.

Astuti, J., Novita, M., \& Ismail, M. S. (2020). Peningkatan Motivasi Belajar Menggunakan Contextual Teaching and Learninf di Madrasah Ibtidaiyah Swasta Raudhatul Mujawwidin Tebo. JURNAL EDUCATIVE: Journal of Educational Studies, https://doi.org/10.30983/educative.v5i1.1630.

Ayatollah. (2018). Upaya Meningkatkan Motivasi dan Hasil Belajar Siswa Pada Mata Pelajaran Pendidkan Agama Islam Menggunakan Metode Demonstrasi Dan Media Nyata Pada Kelas IV SDN 3 Sepit Tahun Pelajaran 2017/2018. FONDATIA: Jurnal Pendidikan Dasar, 2(2), 61-82. https://doi.org/10.36088/fondatia.v2i2.127.

Bildhonn Y, A. F. (2017). Menurunkan Kejenuhan Belajar Siswa Dengan Teknik Relaksasi Pada Mata Pelajaran Pendidikan Jasmani. Profesionalisme Tenaga Profesi Pendidikan Jasmani, Kesehatan, $\begin{array}{lllll}\text { Dan Olahraga, } & 274 & - & 280 . & \text { Retrieved }\end{array}$ http://pasca.um.ac.id/conferences/index.\%0Aphp/por/article/view/666/348.

Buana, D. R. (2020). Analisis Perilaku Masyarakat Indonesia dalam Menghadapi Pandemi Virus Corona (Covid-19) dan Kiat Menjaga Kesejahteraan Jiwa. Salam: Jurnal Sosial Dan Budaya Syar-I, 217226.

Cárdenas-Robledo, L. A., \& Peña-Ayala, A. (2018). Ubiquitous learning: A systematic review. Telematics and Informatics, 35(5), 1097-1132.

Elida. (2018). Peningkatan Motivasi Belajar Pkn Siswa Kelas Ix.7 Smp 21 Kota Pekanbaru Melalui Penerapan Model Pembelajaran Kooperatif Tipe Number Heads Together. DINAMISIA-Jurnal Pengabdian Kepada Masyarakat, 2(1), 13 5-1 43. https://doi.org/10.31849/dinamisia.v2i1.1077.

Emda, A. (2017). Kedudukan motivasi belajar siswa dalam pembelajaran. Lantanida Journal, 5(2), 93-196. https://doi.org/10.22373/lj.v5i2.2838.

Emda, A. (2018). Kedudukan Motivasi Belajar Siswa Dalam Pembelajaran. Lantanida Journal, 5(2), 172. https://doi.org/10.22373/lj.v5i2.2838.

Faridah, E. (2016). Mengajar pendidikan jasmani melalui permainan "ide kreatif mengoptimalkan aspek pedagogis." Jurnal Ilmu Keolahragaan, 15(2), 38-53. 
Fauziah, A. (2017). Hubungan antara Motivasi Belajar dengan Minat Belajar Siswa Kelas IV SDN Poris Gaga 05 Kota Tangerang. Jurnal Pendidikan Sekolah Dasar, 4(1), 47-53. https://doi.org/10.26555/jpsd.v4i1.a9594.

Ginanjar, A., Suherman, A., Juliantine, T., \& Hidayat, Y. (2020). Pengaruh fase sport education menggunakan bola basket terhadap aktivitas fisik siswa dalam pendidikan jasmani. Jurnal SPORTIF: Jurnal Penelitian Pembelajaran, 6(2), 3 32-3 4 7. https://doi.org/10.29407/js_unpgri. v6i2.14173.

Harianto, M. I. F., \& Hartati, S. C. Y. (2016). Perbandingan motivasi belajar siswa dalam mengikuti pembelajaran pendidikan jasmani, olahraga dan kesehatan antara siswa kelas VII SMP Negeri 1 Gondang dengan MTS Miftahul Ulum Gondang, Kabupaten Mojokerto. Jurnal Pendidikan Jasmani, $4(2), 301-306$.

Hartanti, M. D., Nurhasan, \& Tuasikal, A. R. S. (2020). Pengaruh Pembelajaran Sirkuit Berbasis Pendekatan Saintifik Terhadap Hasil Belajar Dribble Dan Shooting Bola Basket. MULTILATERAL: Jurnal Pendidikan Jasmani Dan Olahraga, 19(2), 1-10. https://doi.org/10.20527/multilateral.v19i2.8614.g6741.

Hasmori, A. A., Sarju, H., \& Norihan, I. S. (2011). Pendidikan, kurikulum, dan masyarakat: satu integrasi. Journal of Edupres, 1(September), 350-356. https://doi.org/10.1111/j.14679248.1977.tb01289.x.

Idzhar, A. (2016). Peranan Guru dalam Meningkatkan Motivasi Belajar Siswa. Jurnal Office, 2(2), 221-228.

Iftitah, S. L., \& Anawaty, M. F. (2020). Peran Orang Tua Dalam Mendampingi Anak Di Rumah Selama Pandemi Covid-19. JCE (Journal of Childhood Education), 4(2), 71 - 81. https://doi.org/10.30736/jce.v4i2.256.

Islamiyah, N. A., \& Priambodo, A. (2019). Perbandingan tingkat motivasi belajar siswa antara kelas unggulan dan non unggulan dalam mengikuti pembelajaran pendidikan jasmani, olahraga dan kesehatan di SMA Negeri 7 Surabaya. Jurnal Pendidikan Olahraga Dan Kesehatan, 7(2), 297-300.

Ismawati, D., \& Prasetyo, I. (2021). Efektivitas Pembelajaran Menggunakan Video Zoom Cloud Meeting pada Anak Usia Dini Era Pandemi Covid-19. Jurnal Obsesi : Jurnal Pendidikan Anak Usia Dini, 5(1), 665-675. https://doi.org/10.31004/obsesi.v5i1.671.

Jamal, S. (2017). Pengaruh Motivasi Belajar terhadap Prestasi Belajar IPS Siswa Kelas V III SMP N 2 Srumbung. Social Studies, 6(4), $469-479$.

Koc, Y. (2017). The Effect of "Physical Education and Sport Cult ure" Course on the Attitudes of Preservice Classroom Teachers towards Physical Education and Sports. International Journal of Higher Education, 6(4), 200. https://doi.org/10.5430/ijhe.v6n4p20.

Lesmana, H. S. (2018). Peran Motor Educability Di Dalam Meningkatan Keterampilan Olahraga Pada Pembelajaran Penjas. Jurnal Halaman Olahraga Nusantara, 1(1), 115-125. https://doi.org/10.31851/hon.v1i1.1507.

Mashuri, H. (2017). Persepsi Siswa Terhadap Pembelajaran Guru Pendidikan Jasmani Di Sma Muhammadiyah Kediri. Jurnal Pembelajaran Olahraga, 3(1), 1-10. Retrieved from https://ojs.unpkediri.ac.id/index.php/pjk/article/view/681/505.

Munandar, A., \& Hartati, S. C. Y. (2016). Perbandingan motivasi siswa dalam mengikuti pembelajaran pendidikan jasmani, olahraga dan kesehatan pada siswa kelas 3 dan kelas 5 di SDN Jatilangkung Mojokerto. Jurnal Pendidikan Olahraga Dan Kesehatan, 4(1), 231-235.

Oktiani, I. (2017). Kreativitas Guru dalam Meningkatkan Motivasi Belajar Peserta Didik. Jurnal Kependidikan, 5(2), 216-232. https://doi.org/10.24090/jk.v5i2.1939.

Pambudi, M. I., Winarno, M., \& Dwiyogo, W. D. (2019). Perencanaan dan Pelaksanaan Pembelajaran Pendidikan Jasmani Olahraga Kesehatan. Jurnal Pendidikan Olahraga, Universitas Negeri Malang, 4(1), 110-116.

Rachmah, L. L., Sunaryanto, S., \& Yuniastuti, Y. (2019). Pengaruh Lingkungan Keluarga, Fasilitas Belajar p ada Prestasi Belajar IPS Siswa Ditinjau dari Motivasi Belajar. Jurnal Pendidikan: Teori, Penelitian, Dan Pengembangan, 4(9), 1168-1176.

Ramadhana, W., \& Tuasikal, A. R. S. (2018). Pengaruh permainan modifikasi bola basket terhadap minat belajar siswa kelas V MI NU Tropodo Waru Sidoarjo. Jurnal Pendidikan Olahraga Dan Kesehatan, 06(02), 276-279.

Ramadhani, D., Mahardika, I. M. S., \& Indahwati, N. (2021). Evaluasi Pembelajaran PJOK Berbasis Daring Terhadap Tingkat Pemahaman Dan Motivasi Belajar Siswa Kelas IV - VI SD Negeri Betro, Sedati Sidoarjo. Jurnal Ilmiah Mandala Education, 7(1), 328-338.

Ramli, M. (2015). Hakikat pendidik dan peserta didik. Jurnal Tarbiyah Islamiyah, 5(1), 61-85.

Sadikin, A., \& Hamidah, A. (2020). Pembelajaran Daring di Tengah Wabah Covid-19. Biodik, 6(2), 109-119. https://doi.org/https://doi.org/10.22437/bio.v6i2.9759. 
Sadikin, I. S., Lestari, S., \& Aini, S. (2020). Pembelajaran Daring Interaktif, Bermakna dan Menarik sebagai Upaya Optimalisasi Proses Pembelajaran masa Pandemi Covid -19. Jurnal Pengabdian Pada Masyarakat, 5(4), 897-905. https://doi.org/10.30653/002.202054.647.

Sardiman, A. (2011). Interaksi dan motiasi belajar mengajar. Jakarta: Raja Grafindo Persada.

Sjukur, S. B. (2013). Pengaruh blended learning terhadap motivasi belajar dan hasil belajar siswa di tingkat SMK. Jurnal Pendidikan Vokasi, 2(3), 368-378. https://doi.org/10.21831/jpv.v2i3.1043.

Stephani, M. R. (2017). Stimulasi Kemampuan Berpikir Kritis Melalui Pembelajaran Berbasis Masalah Pada Pendidikan Jasmani. Jurnal Pendidikan Jasmani Dan Olahraga, 2(1), 16-27. https://doi.org/10.17509/jpjo.v2i1.6397.

Suherman, H. dan M. (2020). Potensi Pembelajaran Pendidikan Jasmani Olahraga dan Kesehatan (PJOK) di Tengah Pandemi Corona Virus Disease (Covid)-19 di Sekolah Dasar. Retrieved from http://jurnal.untad.ac.id/jurnal/index.php/PJKR/article/view/16186.

Suryaningtyas, D. (2020). Bekerja dari rumah: implementasinya pada U-Learning selama pandemi virus Covid-19. Jurnal Ekonomi Modernisasi, 16(2), 73-81. https://doi.org/10.21067/jem.v16i2.4837.

Wirawan, M. S. (2017). Motivasi masyarakat terhadap olahraga futsal. Jurnal Pendidikan Kesehatan Dan Rekreasi, 7(3), 17-25.

Yulianto, S., Roesdiyanto, \& Sugiharto. (2017). Analisis Perubahan Kurikulum Pada Proses Pembelajaran Pendidikan Jasmani Olahraga Dan Kesehatan Di Sekolah Dasar. Jurnal Pendidikan: Teori, Penelitian, Dan Pengembang, 2(1), 130 - 140. https://doi.org/10.17977/jp.v2i1.8477. 